\title{
ANTHOCYANINS, BETACYANINS AND THE SYSTEMATICS OF CARYOPHYLLIDS
}

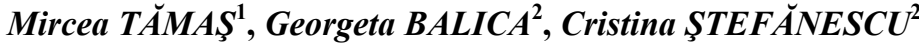 \\ ${ }^{1} 2$ Drapelului st, RO-400475 Cluj-Napoca, Romania \\ ${ }^{2}$ University of Medicine and Pharmacy "Iuliu Haţieganu", Department of Pharmaceutical Botany, \\ 23 Gh. Marinescu st, RO-400337 Cluj-Napoca, Romania \\ e-mail: bgeorgeta@umfcluj.ro
}

\begin{abstract}
This review presents basic information on the two different categories of red vegetal pigments: anthocyanins and betacyanins. To avoid possible confusion between them, we emphasize their biosynthesis, chemical structure, distribution within and among plants and economic aspects, as well as their important pharmacological activities. The betalain derivatives, betacyanins, are found only in one group of Angiosperms, the core Caryophyllales, while anthocyanins are widely distributed among Dicotyledons as well as Monocotyledons. There has been no report so far of anthocyanins and betacyanins existing together within the same plant. The chemical structure of betacyanins is different from that of anthocyanins and their synthesis is derived from amino acids. During evolution, the betalain lineages seem to have been abandoned in favour of the anthocyanin lineages.
\end{abstract}

Keywords: vegetal pigments, antocyanins, betacyanins, betalains, antioxidant activity, Caryophyllales

\section{Introduction}

Anthocyanins and betacyanins represent two categories of vegetal pigments that can both produce a similar array of red colours [21]. On the other hand, betacyanins belong to the larger category of betalains, which include also betaxanthins, which are yellow pigments.

Anthocyanins and betalains occur in a wide range of plant organs (roots, stems, leaves, flowers, fruits, seeds) and in plants from a wide range of natural environments $[10,21,33]$. Both are stored as glycosides in the cell vacuole, sharing similar histological locations in dermal, ground, and vascular tissues of vegetative organs [21].

Being prevalent in flowers and fruits, these pigments are considered to play an important role in the interaction with insects and other animals, attracting pollinators and frugivores for fertilization and seed dispersal $[25,27,33]$. In addition, both are potent antioxidants capable of scavenging many reactive chemical species, have a relatively high osmotic potential (being able to serve possible osmoregulatory roles), and are inducible by similar environmental cues: excess light or UV radiation (offering photoprotection), sucrose accumulation, abiotic stressors such as drought, low temperatures and salinity. These reasons can lead to the conclusion that the two classes of pigments share common functional roles in plants [21,33].

Despite their similarities, the two categories of pigments have different structures and biogenetic origin. Furthermore, betalains occur in a mutually exclusive fashion with anthocyanins, never being found simultaneously in the same plant. Betalains are far less abundant than anthocyanins, and limited to a number of families within the order Caryophyllales and in certain genera of fungi (Amanita, Hygrocybe), hence their importance for plant 
systematics $[6,10,15,21,22,33]$.

In order to eliminate possible confusion between the two classes of red pigments (betacyanins and anthocyanins) and because this subject has not been presented, with a few exceptions [13], in the classic works of plant systematics in Romania [28,30,32,35,42,43], this paper aims to present the families grouping the species containing betacyanins, their chemical structure, biogenesis, phylogenetic and taxonomic role, and their economic and therapeutic value, focusing on the most relevant examples.

\section{Chemical structure, properties, main vegetal sources, and biological activities of anthocyanins}

The data presented in the literature imply that anthocyanins are the most important group of water-soluble pigments in plants, widely present in fruits and vegetables. They are largely found in Dicotyledons as in Monocotyledons [12,17]. The colours determined in plant tissues by these molecules range from blue to purplish-red, with various intermediate tones, sometimes appearing black. The different hues depend on $\mathrm{pH}$ value, molecular structure (number of $\mathrm{OH}, \mathrm{OCH}_{3}$ groups, presence of acyl groups or glycosylation), and presence of co-pigments or complexes with metal ions $[12,17,26,27]$. Anthocyanins are predominantly found in the skin of fruits, while in berries they are present in both the skin and the flesh [8].

They are secondary metabolites and the most important subclass of flavonoids [7]. The anthocyanins are glycosides of anthocyanidins: they are formed by a molecule called aglycone, which is the anthocyanidin, attached to one or several molecules of sugars through a glycosidic bond. The molecules of anthocyanidins represent the basic structure of anthocyanins [7,9,37]. They have a $\mathrm{C}_{6}-\mathrm{C}_{3}-\mathrm{C}_{6}$ skeleton, represented by the flavylium ion [2-phenylbenzopyrylium (2phenylchromenylium) ion] formed of two aromatic groups: a benzopyrilium and a phenolic ring [12]. The two benzene rings ( $A$ and $B$ ), linked by a three-carbon chain forming a pyran ring (C) with an A ring (Fig. 1), have different biogenetic origin: the A ring derives from 3 acetate units through mevalonic acid pathway, while the $\mathrm{B}$ ring derives from a $\mathrm{C}_{6}-\mathrm{C}_{3}$ unit through cinnamic acid pathway $[27,44]$.

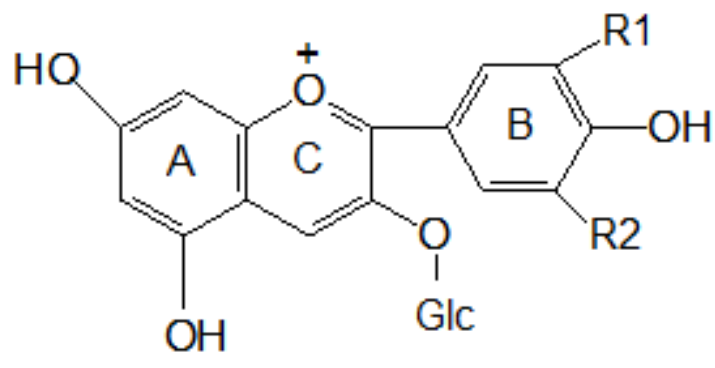

\begin{tabular}{lll} 
R1 & R2 & \multicolumn{1}{c}{ Anthocyanin } \\
$\mathrm{H}$ & $\mathrm{H}$ & Pelargonidin-3-glucoside \\
$\mathrm{OH}$ & $\mathrm{H}$ & Cyanidin-3-glucoside \\
$\mathrm{OH}$ & $\mathrm{OH}$ & Delphinidin-3-glucoside \\
$\mathrm{OCH} 3$ & $\mathrm{H}$ & Peonidin-3-glucoside \\
$\mathrm{OCH} 3$ & $\mathrm{OH}$ & Petunidin-3-glucoside \\
$\mathrm{OCH} 3$ & $\mathrm{OCH} 3$ & Malvidin-3-glucoside
\end{tabular}

Fig. 1: Chemical structure of the 3-glucosides of the six most important anthocyanidins [12]

The free aglycones are rarely found in fresh plant material with the exception of the 3deoxy forms [12,37]. To date, about 700 structurally different anthocyanins have been reported, with the number still increasing, deriving from approximately 30 anthocyanidins [17].

The main differences between them are the basic anthocyanidin skeleton (the number and position of hydroxyl and methoxyl substituents), the nature, number and position of bonded 
sugars, the extent of sugar acylation (the aliphatic or aromatic carboxylates bonded to the sugar and the position of these bonds) [9,12].

The most important anthocyanidins, widely distributed in nature, are the following six: cyanidin, delphinidin, malvidin, pelargonidin, peonidin, petunidin (Fig. 1) [9,12,17,37,44]. The glycosilated derivatives of the non-methylated anthocyanidins (cyanidin, delphinidin, pelargonidin) are the most common in nature, present in $80 \%$ of pigmented leaves, $69 \%$ in fruits and $50 \%$ in flowers $[9,44]$. The distribution of the six important anthocyanidins in fruits and vegetables is as following: $50 \%$ cyanidin, $12 \%$ delphinidin, $7 \%$ malvidin, $12 \%$ pelargonidin, $12 \%$ peonidin, $7 \%$ petunidin [9].

The sugar moieties mainly attached to anthocyanidins are glucose and rhamnose, followed by galactose, xylose, arabinose, and rarely gentiobiose, rutinose, soforose, and sambubiose. The glycosilated derivatives are generally 3-monosides, 3-biosides, 3-triosides, 3,5and 3,7-diglucosides [9,12,37]. The 3-glucoside derivatives are 2.5 more frequent than the 3,5diglucosides, the most common anthocyanin being cyanidin-3-glucoside (Fig. 1) [9].

Anthocyanins can be found in different chemical forms, depending on the $\mathrm{pH}$ of their solution. Also their colour modifies according to the $\mathrm{pH}$ (intensely red at acidic $\mathrm{pH}$, violet at neutral $\mathrm{pH}$, and greenish-blue at basic $\mathrm{pH}$ ). Anthocyanins are more stable at acidic $\mathrm{pH}$. At $\mathrm{pH}$ value of 1 , the red colouring flavylium ion is predominant; at $\mathrm{pH}$ values between 2 and 4 the bluish quinoidal forms are present; at $\mathrm{pH}$ values from 5 to 6 , colourless carbinol pseudobases and chalcones can be identified $[9,41]$.

In some experiments performed by us on aqueous and hydroalcoholic extracts of anthocyanin-containing products (blueberry fruits, elder fruits, hibiscus calyces), compared to betalain-containing products, it was revealed that at high $\mathrm{pH}(9)$, the colour of the anthocyanin extracts turned blue-green. The determined absorption spectra showed only one maximum for the anthocyanin extracts (the characteristic $535 \mathrm{~nm}$ [27]) (Fig. 2).

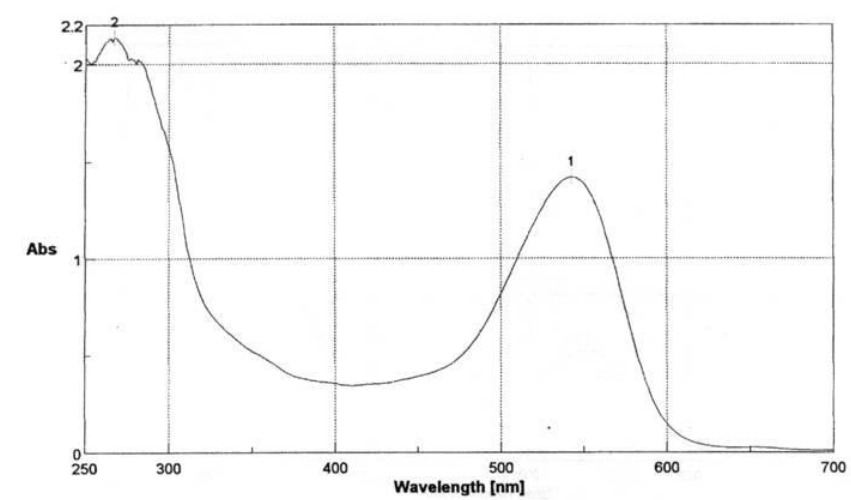

Fig. 2: The UV-VIS absorption spectrum of the acidified methanolic extract from blueberry fruits

Anthocyanins and anthocyanidins are important for their tinctorial properties. At the same time, they have also shown an important antioxidant activity, higher than that of vitamins $\mathrm{C}$ and E [9]. For this reason, correlated with several other mechanisms, these molecules have proved important anti-atherosclerotic or anti-carginogenic properties, and they are thought to prevent cardiovascular diseases, being involved in different activities, such as the prevention of DNA damage, oestrogenic activity, enzymatic inhibition, and the anti-inflammatory response $[1,4,8,24,37]$. Recent studies mention their anti-diabetic, anti-obesity, and anti-neurodegenerative 
properties [17,31,39,44]. Anthocyanin and anthocyanidin extracts have potent capillary permeability regulation activity and promote the activation of retinal circulation and eye adaption to night vision (therefore entering the composition of drug formulas such as DIFRAREL, DIFEBIOM) [18,38,41].

Among dietary flavonoids, anthocyanins are the most consumed [17]. They are present in commonly consumed red, blue or purple fruits and vegetables, in concentrations ranging from $0.1 \%$ up to $1 \%$ [8]. The most important vegetal sources are the fruits of blueberry (Vaccinium myrtillus L.), blackcurrant (Ribes nigrum L.), blackberry (Rubus spp.), red grapes (Vitis vinifera L.), plums (Prunus domestica L.), elder (Sambucus nigra L.), danewort (Sambucus ebulus L.), chokeberry (Aronia melanocarpa (Michx) Elliot), as well as fruit-derived products (juices, red wines) $[8,18,41]$. Other important sources are the flowers of cornflower (Cyanus segetum Hill.), the petals of hollyhock (Alcea rosea L., syn. Althaea rosea (L.) Cav.), the calyx of karkadé (Hibiscus sabdariffa L.) - the last used in medicinal plant infusions to which it gives red colour and acidic taste $[18,41]$.

\section{Chemical structure, properties, main vegetal sources, and biological activities of betalains}

By contrast to anthocyanins, betalains are a class of water-soluble, nitrogen-containing compounds of the chromophore betalamic acid. Betalamic acid [4-(2-oxoethylidene)-1,2,3,4tetrahydropyridine-2,6-dicarboxylic acid] is a tyrosine derivative that constitutes the structural base of all of these compounds. Betalains were originally called "nitrogenous anthocyanins", incorrectly implying structural similarities between the two pigment classes. The name "chromoalkaloids" was also used, due to their biogenesis from amino acids, similar to alkaloids. $[10,18,19,21,23,25]$.

The chemical structure of betalains was discovered later than that of anthocyanins (since 1957). The name "betalain" implied a derivative of betalamic acid which was originally identified in red beetroot (Beta vulgaris L.), hence its name. To date, the structures of about 75 betalains have been identified from different plant families and the number of reported betalains is continuously increasing due to the novel analytical technologies and methodologies in liquid chromatography and mass spectrometry [21,25,33].

Based on the structural characteristics and light-absorption properties, betalains are considered to be of two types: betacyanins - red-violet pigments and betaxanthins - yellow pigments. On the other hand, betacyanins are divided into subgroups: betanin-, gomphrenin-, amaranthin-, and bougainvillein-type pigments. Betacyanins (like betanin) result from the condensation of betalamic acid with cyclo-DOPA (L-DOPA derivative) and can be substituted with sugar and acyl groups. They contain two nitrogen cycles: dihydroxi-indole and metapiridine (Fig. 3). The possibility of glycosilation of betacyanins is similar to that of anthocyanidins (i.e. betanidin is glycosilated by a residue of glucose leading to betanin). Betaxanthins (like indicaxanthin) are immonium derivatives of betalamic acid with different amines and amino acids (Fig. 4) [10,15,18,19,21,23,25,33,34].

Three main enzymes are involved in the biosynthetic pathway of betalains, two of them oxydases (tyrosinase and 4,5-DOPA-extradiol-dioxygenase), while the third transfers a sugar residue in the structure of betacyanins (betanidin-glucosyltransferase). The key enzymes in the biosynthetic pathway are regulated at a transcriptional level [15]. 
<smiles></smiles>

Fig. 3: Chemical structure of betanin

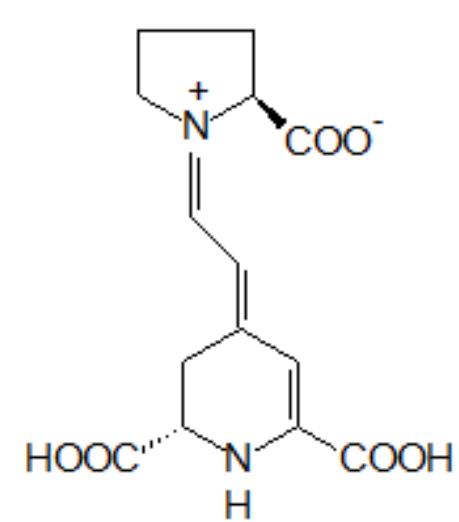

Fig. 4: Chemical structure of indicaxanthin

Considering their light-absorption properties, betacyanins have an absorption maximum at approximately $535-538 \mathrm{~nm}$, while the betaxanthins have one at around $460-480 \mathrm{~nm}$, depending on the molecular structure and type of solvent [10,15,21,23,33].

In the experiments mentioned above, comparing aqueous and hydroalcoholic extracts of anthocyanin-containing products (mentioned above) to betalain-containing products (roots of beetroot, fruits of poke root, flowers of red jalap), at high $\mathrm{pH}$ (9) the colour of the betalain extracts turned yellow. In the absorption spectra determined for betalain extracts two peaks were identified (the characteristic $480 \mathrm{~nm}$ and $530 \mathrm{~nm}$ [10,15,21,23,33]), indicating the presence of both betacyanins and betaxanthins (Fig. 5).

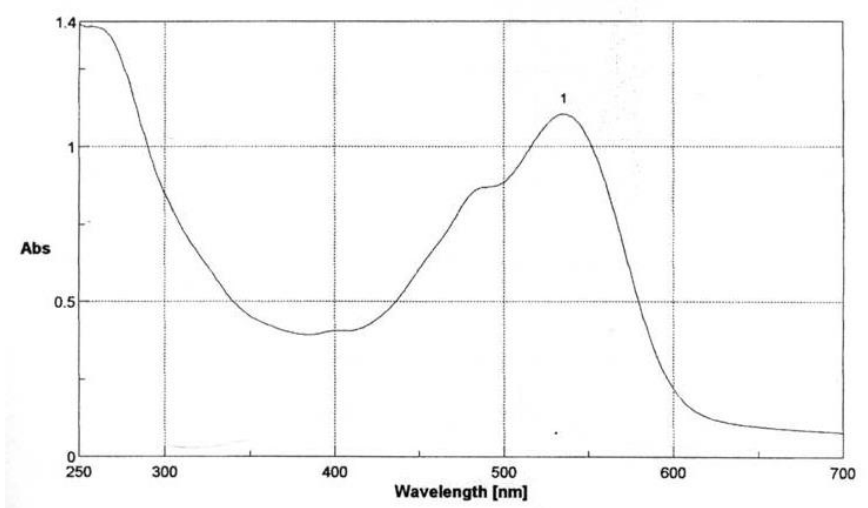

Fig. 5: The UV-VIS absorption spectrum of the aqueous extract from beetroot root

The main known sources of betalains are the root of red and yellow beetroot (Beta vulgaris L. subsp. vulgaris) or coloured Swiss chard (B. vulgaris L. subsp. cicla (L.) W.D.J. Koch), the inflorescences of leaf and grain amaranth (Amaranthus spp.), the flowers and fruits of prickly pear or cactus pear (Opuntia spp.), the fruits of red dragon fruit (red pitahaya) (Hylocereus lemairei (Hook.) Britton \& Rose), the fruits of poke root (Phytolacca americana L.), the flowers of marvel of Peru (Mirabilis jalapa L.), the bracts of bougainvillea 
(Bougainvillea spp.), the petals of purslane (Portulacca spp.). Betalains have also been identified in higher fungi such as Basidiomycetes (Amanita muscaria (L.) Lam.). The major commercially exploited crop is red beetroot, the roots of which contain betanin (a red betacyanin) and vulgaxanthin (a yellow betaxanthin) [10,16,19,25,33,41].

One major interest for utilisation of betalains is as food colourants. They show greatest stability in the $\mathrm{pH}$ range $3.5-7$ and if stored at $4^{\circ} \mathrm{C}$. Therefore, they present interest for frozen foods, low temperature dairy products and foods with a short shelf-life. These pigments are, nevertheless, sensitive to light, heat, high $\mathrm{pH}$, air and metal ions. Beetroot red (or betanin), known as E162, and dehydrated beet (beet powder) are currently the only betalain colorants approved for use in food products in Europe (EU, 2012) and the USA (FDA, 2009) [10,23,25,].

One of the important differences of betalains vis-à-vis anthocyanins is their ability to regenerate after thermal treatment (not observed in anthocyanins). This regeneration is sustained by concomitant use of ascorbic acid, which, on the other hand, affects the stability of anthocyanins, contributing to their degradation [10].

Known not only for their tinctorial properties and basis for numerous dietary supplement products, betalains proved to be important bioactive molecules with strong antioxidant activity. Some effects attributed to them are anti-proliferative (dose-dependent inhibition of cancer cells growth and proliferation; inhibition of formation of tumours in vivo in mice), hypolipidemic, hepatoprotective, cardioprotective, anti-inflammatory, anti-microbial, and anti-diabetic. They proved to ameliorate obesity and insulin-resistance in mice fed a high-fat diet [10,15,33]. Other potential uses of these compounds are in dye-sensitized solar cells, as textile dyes, as chemical biosensors, protein-labelling fluorophores, and markers for genetic transformation $[29,33,36]$.

\section{Taxonomic relevance of anthocyanins and betalains}

While anthocyanins are widely distributed among the Angiosperms [12,17], betalains (betacyanins and betaxanthins) are found in only one group of angiosperms, the order Caryophyllales within the subclass Caryophyllidae [6,15,21,23,25,33,34].

In the Cronquist classification, the order Caryophyllales is included in the subclass Caryophyllidae, along with the orders Polygonales and Plumbaginales, the pigments present in these two latest orders being anthocyanins $[20,25,41]$. In older classification systems (Wettstein), the order Caryopyllales was known as Centrospermales (Centrospermae) and was placed, based on the central placentation, among the Monochlamids along with the orders Fagales, Salicales, Urticales, etc. [28,35]. In other systems, the order is included among the Caryophyllids, a clade considered by Cronquist and Guignard as a heterogeneous one, grouping together apetals, dyalipetals and gamopetals. They consider it a subclass of dicotyledons with primitive characteristics, similar to Magnoliids (Fig. 6) [18,19,25].

The main elements that characterize the order Caryophyllales include the free-central or basal placentation, the curved ovule which determines a curved embryo, and the presence of perisperm (within the curved area) instead of endosperm as seed storage tissue. Another important character is that all Caryophyllales families (except for Caryophyllaceae and Molluginaceae) synthesise betalain pigments instead of anthocyanins, the latter being ubiquitous in all the other spermatophytes and in pteridophytes. This order possesses bound ferulic acid in unlignified cell-walls, a characteristic known only in some monocotyledons. Also, it was revealed that Caryophyllales have a specific type of sieve-element plastids, in which a peripheral 
ring of proteinaceous filaments surrounds a protein crystal that is globular or angular in shape [14].

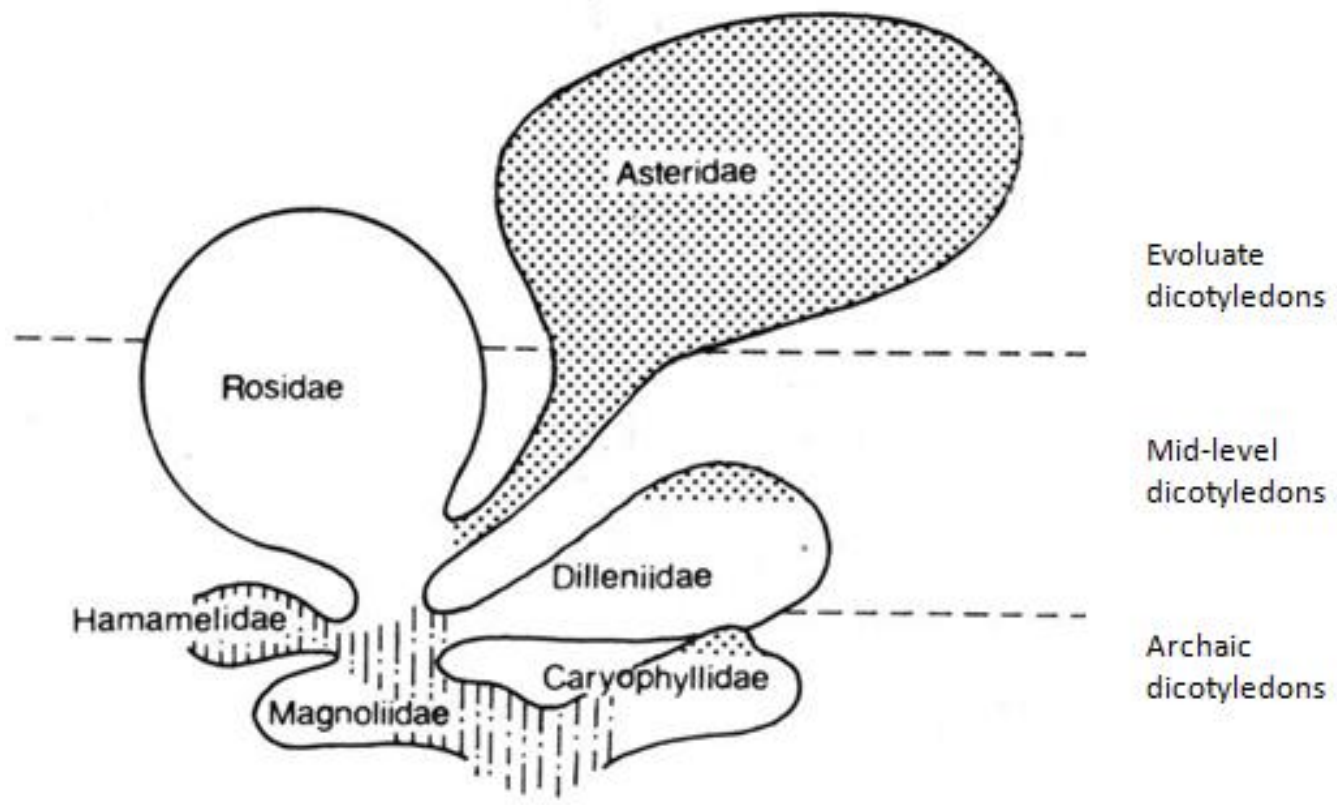

Fig. 6: Evolutionary relationship amongst the subclasses of dicotyledons, after Cronquist. The surface of each area is proportionate to the number of species in each group.

Dashed - apetals; white - dialypetals; dotted - gamopetals [19]

Cronquist and Thorne, in 1994, circumscribed the order Caryophyllales to comprise 11 families: Aizoaceae, Amaranthaceae, Basellaceae, Cactaceae, Caryophyllaceae, Chenopodiaceae, Didiereaceae, Molluginaceae, Nyctaginaceae, Phytolaccaceae, and Portulacaceae [14].

Within this order, only the species belonging to Caryophyllaceae (Stellaria, etc.) and Molluginaceae (Molugo, etc.) synthesize anthocyanins [6,14,21,25,33,34].

The other families of Caryophyllales contain only betalains (betacyanins and betaxanthins): Aizoaceae (Mesembryanthemum, Lithops), Amaranthaceae (Amaranthus, Celosia, Gomphrena, etc.), Basellaceae (Basella, etc.), Cactaceae (Cereus, Mammillaria, Opuntia, Phyllocactus, etc.), Chenopodiaceae (Beta, Chenopodium, Suaeda, Atriplex, etc.), Nyctaginaceae (Bougainvillea, Mirabilis, etc.), Phytolaccaceae (Phytolacca, etc.), Portulacaceae (Portulaca, etc.). The little family Didieraceae, comprising species endemic to Madagascar (Alluaudia, etc.), was included in this order based on the presence of betacyanins as red pigments [6,14,25].

Previously, in the order Caryophyllales was included, based on the morphological characters, the family Batidaceae which lacks red pigments [25]. To date, this family is known as Bataceae, and is included in the order Brassicales sensu APG IV [40].

Modern classification systems (Angiosperm Phylogeny Group (APG) systems) place the order Caryophyllales as follows: in APG III (2009) it is classified under the Core Eudicots belonging to Eudicots clade in the Angiospermae [2]; in APG IV (2016) it is classified under the Superasterides belonging to Eudicots clade in the Angiospermae [3].

Molecular systematic studies have added numerous further families to the order 
Caryophyllales, including Polygonaceae, Plumbaginaceae, Droseraceae, Nepenthaceae, Rhabdodendraceae, Tamaricaceae. A broader understanding of the phylogeny of the systematic families led the APG (1998) to introduce the concept of "expanded Caryophyllales", comprising many more families, whereas the traditionally recognised Centrospermae is referred to as "core Caryophyllales" [14].

Also, some new families have been recognised over time, deriving from the traditional ones. To date, the APG IV classification (2016) comprises the following families for the order Caryophyllales: Achatocarpaceae, Aizoaceae, Amaranthaceae, Anacampserotaceae, Ancistrocladaceae, Asteropeiaceae, Barbeuiaceae, Basellaceae, Cactaceae, Caryophyllaceae, Didieraceae, Dioncophyllaceae, Droseraceae, Drosophyllaceae, Frankeniaceae, Gisekiaceae, Halophytaceae, Kewaceae, Limeaceae, Lophiocarpaceae, Macarthuriaceae, Microteaceae, Molluginaceae, Montiaceae, Nepenthaceae, Nyctaginaceae, Physenaceae, Phytolaccaceae, Plumbaginaceae, Polygonaceae, Portulacaceae, Rhabdodendraceae, Petiveriaceae, Sarcobataceae, Simmondsiaceae, Stegnospermataceae, Talinaceae, Tamaricaceae [40].

From this point of view, the presence of betalains is a characteristic of core Caryophyllales, whereas in the other families from expanded Caryophyllales the anthocyanins being present $[6,34]$.

Brockington et al. (2015) indicate the following families from core Caryophyllales that contain betalains: Amaranthaceae (including Chenopodiaceae), Stegnospermataceae (formerly included in Phytolaccaceae), Aizoaceae, Giseckiaceae (formerly included in Phytolaccaceae), Phytolaccaceae, Rivinaceae (to date Petiveriaceae sensu APG IV, formerly included in Phytolaccaceae), Sarcobataceae (formerly included in Chenopodiaceae), Nyctaginaceae, Montiaceae (formerly included in Portulaccaceae), Basellaceae, Didieraceae, Talinaceae (formerly included in Portulaccaceae), Portulaccaceae, Cactaceae [2,3,6,20].

They also mention the exceptions from the core Caryophyllales that contain antocyanins instead of betalains: Caryophyllaceae, Molluginaceae, Kewaceae (Kewa, formerly Hypertelis from Molluginaceae), Macarthuriaceae (Macarthuria, formerly included in Molluginaceae) $[6,11,34]$.

It is considered that those species lost the capacity of synthesizing betalains in favour of anthocyanins which lack nitrogen. The presence of betalains is considered an archaic character, their synthesis not being economical - the limiting element is the nitrogen required for the synthesis of amino acids, nitrogenous bases and chlorophyll. It is also interesting to see that several families with betalains include anthropophilic and nitrophilic species [18,25]. The Centrospermae are plants with a long history, from the Upper Cretaceous. Those theories explained that the ancestor of the Caryophyllales could have held both types of pigments, one type being lost during plant evolution. Recent studies using $\mathrm{rbcL} / \mathrm{matK}$ plastid gene markers have shown that the ancestral type was almost certainly anthocyanic and that betalain pigmentation arose early in the evolution of the Caryophyllales, being then lost in anthocyanic lineages. It seems also that the capacity to synthesise betalains may have arisen more than once, followed by the switch to anthocyanin production. Therefore, there has to be some 'cost' associated with betalain synthesis, which drives evolution towards anthocyanic rather than betalainic plants. The different data have also revealed that the long-term exclusion of betalain pigments from anthocyanic taxa is mediated through gene loss, while the suppression of anthocyanins in betalain species is rather at the regulatory level $[5,6,21]$. 


\section{Conclusions}

1. Betalains are pigments found only in families belonging to the order Caryophyllales (core Caryophyllales sensu APG), which gives them a high taxonomic value.

2. Betacyanins and anthocyanins are red pigments that mutually exclude each other, seeming to perform similar functions in the interaction between plants and their environment or with animals for pollination and seed dispersal.

3. Betacyanins are structurally different from anthocyanins, containing two nitrogen atoms in the molecule. Their synthesis in plants is derived from amino acids and they can be considered as a nitrogen reserve for plants.

4. The taxonomic value of betalains is higher for families and smaller for genera and species within the same family.

5. During plant evolution, the betalain lineages might have been abandoned in the favour of anthocyanin lineages.

6. Knowing the distribution of the two categories of red pigments in plants is important not only for taxonomy, but also for their use as food colorants having distinct chemical and biological properties.

7. We have the confirmation of the importance of secondary metabolites as taxonomic markers for the Magnoliophytae.

\section{REFERENCES}

1. Aboonabi, A., Singh, I., 2015, Chemopreventive role of anthocyanins in atherosclerosis via activation of Nrf2-ARE as an indicator and modulator of redox, Biomedicine \& Pharmacotherapy, 72: 30-36.

2. APG III, 2009, An update of the Angiosperm Phylogeny Group classification for the orders and families of flowering plants: APG III, Botanical Journal of the Linnean Society, 16: 105-121.

3. APG IV, 2016, An update of the Angiosperm Phylogeny Group classification for the orders and families of flowering plants: APG IV, Botanical Journal of the Linnean Society, 181: 1-20.

4. Braga, A.R.C., Murador, D.C., de Souza, Mesquita, L.M., de Roso, V.V., 2018, Bioavailability of anthocyanins: Gaps in knowledge, challenges and future research, Journal of Food Composition and Analysis, 68: 31-40.

5. Brockington, S.F., Walker, R.H., Glover, B.J., Soltis, P.S., Soltis, D.E., 2011, Complex pigment evolution in the Cariophyllales, New Phytologist, 190: 854-864.

6. Brockington, S.F., Yang, Y., Gandia-Herrero, F., Covshoff, S., Hibberd, J.M., Sage, R.F., Wong, G.K.S., Moore, M.J., Smith, S.A., 2015, Lineage-specific gene radiations underlie the evolution of novel betalain pigmentation in Caryophyllales, New Phytologist, 207: 1170-1180.

7. Bunea, A., Rugină, D., Sconţa, Z., Pop, R.M., Pintea, A., Socaciu, C., Tăbăran, F., Grootaert, C., Struijs, K., VanCamp, J., 2013, Anthocyanin determination in blueberry extracts from various cultivars and their antiproliferative and apoptotic properties in B16-F10 metastatic murine melanoma cells, Phytochemistry, 95: 436-444.

8. Cassidy, A., 2017, Berry anthocyanin intake and cardiovascular health, Molecular Aspects of Medicine, xxx: $1-7$.

9. Castañeda-Ovando, A., de Lourde,s Pacheco-Hernández, M.-L., Páez-Hernández, M.E., Rodriguez, J.A., Gálan-Vidal, G.A., 2009, Chemical studies of anthocyanins: A review, Food Chemistry, 113: 859-871.

10. Celli, G.B., Brooks, M.S-L., 2017, Impact of extraction and processing conditions on betalains and comparison of properties with anthocyanins - A current review, Food Research International, 100: 501-509. 
11. Christenhusz, M.J.M., Brockington, S.F., Christin, P-A., Sage, R.F., 2014, On the disintegration of Molluginaceae: a new genus and family (Kewa, Kewaceae) segregated from Hypertelis, and placement of Macarthuria in Macarthuriaceae, Phytotaxa, 181 (4): 238-242.

12. Clifford, M.N., 2000, Anthocyanins - nature, occurrence and dietary burden, Journal of the Science of Food and Agriculture, 80: 1063-1072.

13. Cristea, V., 2014, Plante vasculare: diversitate, sistematică, ecologie şi importanţă, Presa Universitară Clujeană, Cluj-Napoca.

14. Cuenoud, P., 2003, Introduction to Expanded Caryophyllales. In: Kubitzki, K., Bayer, C. (eds.), Flowering Plants: Dicotyledons, The Families and Genera of Vascular Plants, vol 5. Springer, Berlin, Heidelberg.

15. Gandia-Herrero, F., Garcia-Carmona, F., 2013, Biosynthesis of betalains: yellow and violet plant pigments, Trends in Plant Science, 18 (6): 334-343.

16. Gengatharan, A., Dykes, G.A., Choo, W.S., 2015, Betalains: Natural plant pigments with potential application in functional foods, Food Science and Technology, 64: 645-649.

17. Gowd, V., Jia, Z., Chen, W., 2017, Antocyanins as promising molecules and dietary bioactive components against diabetes - A review of recent advances, Trends in Food Science \& Technology, 68: 1-13.

18. Guignard, J.-L., 2000, Biochimie végétale, $2^{\mathrm{e}}$ édition. Dunard, Paris.

19. Guignard, J.-L., 1998, Botanique II édition. Masson, Paris, Milan, Barcelona.

20. Heywood, V.H., 1978, Flowering plants of the world, Oxford University Press, Oxford, London, Melbourne.

21. Jain, G., Gould, K.S., 2015, Are betalain pigments the functional homologues of anthocyanins in plants? Environmental and Experimental Botany, 119: 48-53.

22. Khan, M.I., Giridhar, P., 2015, Plant betalains: Chemistry and biochemistry, Phytochemistry, 117: 267-295.

23. Khan, M.I., 2016, Stabilization of betalains: A review, Food Chemistry, 197: 1280-1285.

24. Liobikas, J., Skemiene, K., 2016, Trumbeckaite S., Borutaite V., Anthocyanins in cardioprotection: A path through mitochondria, Pharmacological Research, 113: 808-815.

25. Mabry, T.J., 1966, The betacyanins and betaxanthins in "Comparative Phytochemistry", (Swain T. editor), Academic Press, London-New York.

26. Markakis, P., 1982, Anthocyanins as Food Colors, Academic Press, New-York-London-Paris.

27. Markham, K.R., 1982, Techniques of Flavonoid Identification, Academic Press, London-New-York-Paris.

28. Moraru, I., Todor, I., 1972, Botanică sistematică, Editura Didadictică şi Pedagogică, Bucureşti.

29. Oprea, C.I., Dumbravă, A., Enache, I., Georgescu, A., Gîrţu, M.A., 2012, A combined and experimental and theoretical study of natural betalain pigments used in dye-sensitized solar cells, Journal of Phytochemistry and Photobiology, A: Chemistry, 240: 5-13.

30. Oroian, S., 2011, Botanică farmaceutică, Editura University Press, Târgu Mureş,

31. Pacheco, S.M., Soares, M.S.P., Gutierres, J.M., Gerzson, M.F.B., Carvalho, F.B., Azambuja, J.H., Schetinger, M.R.C., Stefanello, F.M., Spanevello, R.M., 2018, Anthocyanins as a potential pharmacological agent to manage memory deficit, oxidative stress and alteration in ion pump activity induced by experimental sporadic dementia of Alzheimer's type, Journal of Nutritional Biochemistry, 56: 193-204.

32. Palade, M., 1998, Botanică farmaceutică - Sistematică generală, Vol. 2. Editura Tehnică, București.

33. Polturak, G., Aharoni, A., 2018, "La vie en rose": biosynthesis, sources, and application of betalain pigments, Molecular Plant, 11:7-22.

34. Polturak, G., Heinig, U., Grossman, N., Battat, M., Leshkowitz, D., Malitsky, S., Rogachev, I., Aharoni, A., 2018, Transcriptome and metabolic profiling provides insights into betalain biosynthesis and evolution in Mirabilis jalapa, Molecular Plant, 11: 189-204.

35. Pop, I., Hodişan, I., Mititelu, D., L., Lungu, I., Cristurean, Gh., Mihai, 1983, Botanică sistematică, Editura Didactică şi Pedagogică, Bucureşti.

36. Rodrigues, A.C.B., Mariz, I.F.A., Maçoas, E.M.S., Tonelli, R.R., Martinho, J.M.G., Quina, F.H., Bastos, E.L., 2018, Bioinspired water-soluble two-photon fluorophores, Dyes and Pigments, 150: 105-111.

37. Santhakumar, A.B., Battino, M., Alvarez-Suarez, J.M., 2018, Dietary polyphenols: Structure, bioavailability and protective effects against atherosclerosis, Food and Chemical Toxicology, 113: 49-65.

38. Skibsted, L.H., 2018, Anthocyanidins regenerating xanthophylls: a quantum mechanical approach to eye health, Current Opinion in Food Science, 20: 24-29.

39. Spagnuolo, C., Moccia, S., Russo, G.L., 2017, Anti-inflammatory effects of flavonoids in neurodegenerative disorders, European Journal of Medical Chemistry, xxx: 1-11. 
40. Stevens, P.F., (2001 onwards), Angiosperm Phylogeny Website. Version 14, July 2017 [and more or less continuously updated since]. http://www.mobot.org/MOBOT/research/APweb/.

41. Tămaş, M., 2004, Botanică farmaceutică, Vol. I, Citologie, Editura Medicală Universitară "Iuliu Haţieganu", Cluj-Napoca.

42. Tămaş, M., 1999, Botanică farmaceutică, Vol. III, Sistematica-Cormobionta, Editura Medicală Universitară "Iuliu Haţieganu", Cluj-Napoca.

43. Tiţă, I., 2008, Botanică farmaceutică, Ed.a III-a, Editura Sitech, Craiova.

44. Xie, L., Su, H., Sun, C., Zheng, X., Chen, W., 2018, Recent advances in understanding the anti-obesity activity of anthocyanins and their biosynthesis in microorganisms, Trends in Food Science and Technology, 72:13-24.

\section{ANTOCIANII, BETACIANINELE ŞI SISTEMATICA CARIOPHYLLIDELOR}

\section{(Rezumat)}

Acest articol de sinteză prezintă informaţii esenţiale despre două categorii diferite de pigmenţi vegetali roşii: antocianii şi betacianinele. Pentru a evita confuzia între cele două, argumentele noastre se referă la biosinteza, structura chimică, răspândirea şi importanţa economică, precum şi la activităţile farmacologice ale acestora. În timp ce antocianii au o răspândire largă la Dicotiledonate şi Monocotiledonate, derivaţii de betalaină, betacianinele, se găsesc numai într-un singur grup de Angiosperme, nucleul Caryophyllales. Nu există până acum dovezi care să arate că antocianii şi betacianinele sunt sintetizaţi simultan în aceeaşi plantă. Structura chimică a betacianinelor este diferită de cea a antocianilor. Sinteza betacianinelor derivă din aminoacizi, rezultând din condensarea acidului betalamic cu ciclo-DOPA, în timp ce antocianii fac parte din clasa flavonoidelor, biosinteza acestora fiind realizată pe calea acizilor mevalonic, respectiv cinamic. Prezenţa betacianinelor este considerată un caracter arhaic; în decursul evoluţiei, se presupune că sinteza acestora a fost abandonată în favoarea sintezei antocianilor. Referitor la proprietăţile farmacologice, ambele categorii de pigmenţi au dovedit o acţiune puternică antioxidantă, având efecte promiţătoare cardioprotectoare, hipolipidemice, antiinflamatoare, antidiabetice. 